\title{
高性能爆薬の水中爆ごうにより発生した水中衝軞波の基本特性*
}

\author{
伊東繁*1, 灘 光陽*2, 吉 良章 夫*3 \\ 長 野司 郎*1, 藤 田昌 大*1, 本田隆 志*2
}

\section{Fundamental Characteristics of Underwater Shock Wave due to Underwater Explosion of High Explosives}

\author{
Shigeru ITOH, You NADAMITSU, Akio KIRA, \\ Shiro NAGANO, Masahiro FUJITA and Takashi HONDA
}

\begin{abstract}
Fundamental characteristics of underwater shock waves generated by underwater explosion of high explosives are investigated by both experimentally and by numerical simulation. The attenuation process of the underwater shock wave is also investigated theoretically using a method of characteristics. Slab explosives are used in the experiments. Streak photographs are taken by a high speed camera using a conventional shadowgraph system. When the detonation wave propagates into the explosive, the underwater shock wave is generated at the boundary between the slab explosives and the water. The incident angle of the underwater shock wave is the same as that obtained by the impedance matching method between the explosives and water. The angle then changes due to the effects of interaction with the expansion wave occurring due to the expanded product gas. The attenuation process of the underwater shock wave is well explained by the method of characteristics.
\end{abstract}

Key Words: Shock Wave, Method of Characteristics, Detonation, Numerical Analysis, Expansion Wave, Shock Attenuation

\section{1. 緒}

著者らは高性能爆薬を水中で爆ごうさせ，それによ って発生した水中衝撃波を利用した各種金属加工法を 研究してきた。例えば金属円管内に水中衝撃波を導入 させた円管の内側からの側壁の孔あけ加工(1), 成形型 を用いた球款の爆発成形(2)，あるいは高難度焼結粉末 の衝擊固化(3) 等について報告してきた。これらの金属 加工を行う場合, 高性能爆楽の水中爆ごうによって発 生した水中衝撃波を加工目的にあうように有効に制御 しなければならない，高性能爆楽を水中爆ごうさせる と，爆ごう波の伝ぱに伴って水中衝撃波が水中に発生 し伝ぱする。このような現象のうち爆源から離れた場 所における水中衝擊波の挙動については Cole ${ }^{(4)}$, Sternberg $^{(5)}$ らによって詳細に研究されている。しか し爆薬近傍に扔ける水中衝撃波の基本特性はまだ十分 には明らかにされていない。

著者らは，高性能爆薬の爆ごうにより生じた爆ごう 生成ガスの Jones-Wilkins-Lee (JWL) 状態方程式(6)

\footnotetext{
*1995 年11月18日 山口地方講演会で講演, 原稿受付 1996 年1月 11 日.

*1 正員, 熊本大学工学部 ( 8862 熊本市黑髮 2-39-1).

*2 正員, 第一工業大学工学部（日958-12 国分市中央 1-10-2).

*3 正貣, 熊本大学大学院.
}

をシリンダ膨張試験で求めた。その状態方程式を用い て高性能爆薬の水中爆ごう過程ならびにそれによっ て生ずる水中衝撃波の伝ば過程を Arbitrary Lagran gian Eulerian(ALE) 法(7)により数值計算し，その結 果とシャドウグラフ法によって実験的に得られた水中 衝撃波の形状を比較し両者がよく一致することを明ら かにした ${ }^{(8)}$ ：その場合水中衝撃波の形状変化と強さの 減衰過程がきわめて強い関係にあることを定性的に述 べた(9).また円筒形爆薬の水中爆ごうによって生ずる 水中衝撃波の伝ぱならびに減衰過程についても報告 し，爆ごう生成ガスの膨張によって生ずる膨張波と水 中衝撃波の王涉過程を実験ならびに数値計算によって 解析した(10).これらの実験結果から水中衝撃波の減衰 過程が爆ごう生成ガスの膨張によって生ずる膨張波の 影響を大きく受けることを明らかにした，本報ではこ れらの結果に基づき特性理論を適用した理論解析を提 案し，実験的に得られた水中衝撃波の形状から爆ごう 生成ガスの膨張過程を明らかにする。この解析では， 前述の数值計算法と異なり爆ごう生成ガスの状態方程 式が末知の爆薬でも，水中衝撃波の形状がわかれば， 水中爆ごう過程における爆ごう生成ガスの膨張過程を 明らかにすることが可能となる，この解析結果と，平 板状に成形された爆薬を Polymethylmethacrylate 
(PMMA)板にはり水中で爆ごうさせて得られた実験 結果を比較し, 本理論の有用性について述べる。

\section{2. おもな記号}
$X:$ 平板に沿った座標
$Y:$ 平板に垂直な座標
$P$ :圧力
$\rho$ : 密度
$e:$ 比内部エネルギー
$D$ : 爆ごう波の速度
$U_{s}$ : 水中衝擊波先頭の速度
$u_{p}:$ 粒子速度
$v$ : 定置座標系での粒子速度
$C$ : 音速
$M:$ マッ八数
$\mu$ :マッ八角
$\nu$ : Prandtl-Meyer 関数
$\delta:$ 流れの転向角
$\theta$ : 水中衝擊波の接線角
$\Gamma$ : Grüneisen 係数

下添字 0 は大気圧, 常温における状態を表す. その他 の記号は文章中で定義する。

\section{3. 理 論 解 析}

図 1 は爆ごう波を固定した定置座標系で表した水中 衝撃波系を示す。理論解析では爆楽の爆ごう特性なら びに水中衝撃波の卮ぱ過程に以下の仮定を行う。

（1）爆薬中を伝ぱする爆ごう波は一定速度 $D$ て 伝ぱし，定常理想爆ごうを行う。

（2）水中衝撃波は同一形状を保ち爆ごう波ととも に図 1 中 $X$ 方向に一定速度 $D$ で移動する。

（3）流れ場全体に $X$ 方向に逆向きに速度 $D$ を加 えることによって爆ごう波ならびに水中衝擊波を静止 することができる。

仮定 (1) は高性能爆薬のもっている性質であるが, 爆

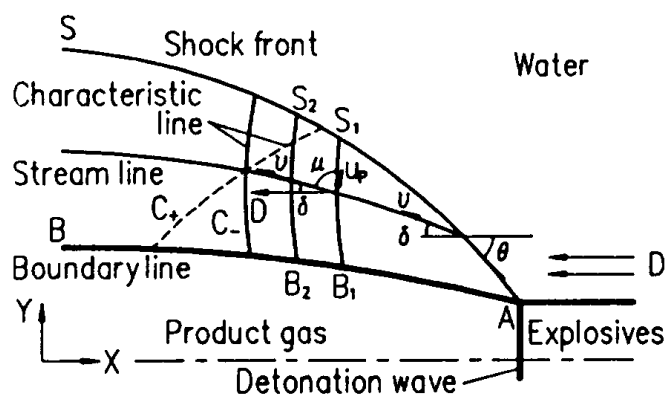

Fig. 1 Stationary coordinate system of the underwater shock wave
薬の寸法等の影響によって䈯密には成り立たない場合 が多い。ここではその仮定が㛜密に式り立つとする. 仮定 (2)より， $U_{s}$ と $D$ に対して次の関係が成り立 $\supset^{(11)}$.

$$
U_{s}=D \sin \theta
$$

定置座標系で爆ごう生成ガスと水との境界を曲線 $\mathrm{AB}$ で示す。この境界と水中衝撃波 AS との間に特性曲線 (図 1 中の曲線 SB) を描くことができる。現象が二次 元である場合は仮定 $(1)$ ，（3）よりこの特性曲線 $C_{-}$ に浻ってリーマン量 $R$ は一定で次式が成り立つ。

$$
\begin{aligned}
& R=\nu-\delta=\text { const } \\
& d \delta=d \nu=\sqrt{M^{2}-1} \frac{d v}{v}, M=\frac{v}{C} \\
& d P=\frac{-\rho v^{2}}{\sqrt{M^{2}-1}} d \delta
\end{aligned}
$$

同様に特性曲線 $C+$ に沿ってリーマン量 $Q$ は一定で 次式が成り立つ。

$$
\begin{aligned}
& Q=\nu+\delta=\text { const } \\
& d \delta=-d \nu \\
& d P=\frac{\rho v^{2}}{\sqrt{M^{2}-1}} d \delta
\end{aligned}
$$

ここで経験的に知られる関係式 $U_{s}=C_{0}+s u_{p}$ を斜め 衝擊波の関係式に適用すると水中衝撃波面に浻ったり ーマン量の変化は $U_{s}$ の関数となる. $s$ は体積弾性率 の圧力微分 $K_{0}^{\prime}$ を用いて $s=\left(K_{0}^{\prime}+1\right) / 4$ で表される.ま た水中衝撃波面 $\mathrm{S}$ に沿ったリーマン量の変化 $d R_{S}$ と 境界面 $\mathrm{B}$ に为ったリーマン量の変化 $d R_{B}$ は等しくな ければならない.よって次式を得る。

$$
\begin{aligned}
& \int_{s_{1}}^{s_{2}}\left(\frac{d \nu}{d U_{s}}-\frac{d \delta}{d U_{s}}\right) d U_{s} \\
& =\int_{B_{1}}^{B_{2}} \sqrt{M^{2}+1} \frac{d v}{v}-\int_{B_{1}}^{B_{2}} d \delta
\end{aligned}
$$

式（3）を代入して

$$
\int_{s_{1}}^{s_{2}}\left(\frac{d \nu}{d U_{s}}-\frac{d \delta}{d U_{s}}\right) d U_{s}=-2 \int_{B_{1}}^{B_{2}} d \delta
$$

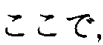

$$
\begin{aligned}
& \frac{d \nu}{d U_{s}}=\frac{\sqrt{M^{2}-1}\left\{U_{s}(1-2 s)+C_{0}(s-1)\right\}}{\left\{U_{s}^{2}(1-2 s)+2 U_{s} C_{0}(s-1)+C_{0}^{2}+s^{2} D^{2}\right\}} \\
& v^{2}=\frac{\left\{U_{s}(s-1)+C_{0}\right\}^{2}}{s^{2}}+D^{2}-U_{s}^{2} \quad \cdots \cdots \cdots \cdots(6)
\end{aligned}
$$

また $\delta と U_{s}$ との間には次の関係がある.

$$
\begin{aligned}
& \tan \delta=\frac{\left(U_{s}-C_{0}\right) \sqrt{D^{2}-U_{s}^{2}}}{s D^{2}-U_{s}\left(U_{s}-C_{0}\right)} \\
& \frac{d \delta}{d U_{s}} \\
& =\frac{s\left(D^{2}-U_{s}^{2}\right)-\left(U_{s}-C_{0}\right)\left\{(s-1) U_{s}+C_{0}\right\}}{\left[s^{2} D^{2}-\left(U_{s}-C_{0}\right)\left\{(2 s-1) U_{s}+C_{0}\right\}\right] \sqrt{D^{2}-U_{s}^{2}}}
\end{aligned}
$$

流線に沿って次式が成り立つ。 
Table 1 Parameters of equation of state

\begin{tabular}{|c|c|c|c|c|}
\hline Material & $\rho_{0}\left(\mathrm{~kg} / \mathrm{m}^{3}\right)$ & $C_{0}(\mathrm{~m} / \mathrm{s})$ & $s$ & $\Gamma$ \\
\hline PMMA & 1181.0 & 2260.0 & 1.816 & 0.75 \\
\hline Water & 1000.0 & 1489.0 & 1.786 & 1.65 \\
\hline
\end{tabular}

$$
\begin{aligned}
& v_{2}^{2}-v_{1}^{2}=-2 \int_{\rho_{1}}^{\rho_{2}} \frac{C^{2}}{\rho} d \rho \\
& \frac{d P}{d \rho}=C^{2}
\end{aligned}
$$

なお $C$ は次式で与えられる。

$$
C=C_{0}(1-\eta) \frac{\sqrt{\{1+s \eta(1-\Gamma \eta)\}}}{(1-s \eta)^{1.5}}
$$

ここで $\eta=1-\rho_{0} / \rho$ である.

水中衝撃波の形状あるいは爆ごう生成ガスと水との 境界の位置および物理量が与えられると以上の関係式 から, AS と AB 間の領域の物理量が得られる。また 図 1 点 $\mathrm{A} て ゙ の$ 水中衝擊波の強さと入射角はインピー ダンスマッチング法から求められる(12).ここで水扔よ び PMMA の $\rho_{0}, C_{0}, s, \Gamma$ を表 $1^{(13)(14)}$ に示す.

\section{4. 実験方法および数怵計算方法}

4・1 水中街慗波の光学的写真锶宗実験 高性能 爆薬 SEP [旭化成工業(株) 製, PETN : 65\%, Paraffine : $35 \%$, 充てん密度 $\rho_{e}=1310 \mathrm{~kg} / \mathrm{m}^{3}, D=$ $6970 \mathrm{~m} / \mathrm{s}$ )を実験に用いた。爆薬を平板状に成形し，そ れをPMMA 板にはった. SEP の形状および寸法を図 2 に示す. 主爆薬の寸法は厚さ $h$ が $3 \mathrm{~mm}$, 長さが 150 $\mathrm{mm}$ で，爆薬の側端面から発生した膨張波の影響をみ るために，幅 $H$ をそれぞれ $30,60,90,120 \mathrm{~mm}$ とか えた。さらに $h$ の影響をみるために $h=5 \mathrm{~mm}, H=50$ $\mathrm{mm}$ の実験もあわせて行った。主爆薬内を伝ぱする爆 ごう波が平面になるように, SEP と HABW [九但化成 工業(株) 製, $\rho_{e}=2200 \mathrm{~kg} / \mathrm{m}^{3}, D=4750 \mathrm{~m} / \mathrm{s}$ ] て構成 された爆楽レンズを主爆薬の前に配置した。この爆葲 を水で満たしたPMMA 製の水槽に入れて電気雷管に よって起爆させ，中水爆ごう実験を行った．水中爆ご う実験装置を図 3 に示す。

光学的写真観察実験は, キセノンフラッシュライト (HADLAND PHOTONICS 社製, HL 20/50 形フラ ッシュュニット, 出力 $500 \mathrm{~J}$, 女ん光時間 $50 \mu \mathrm{S}$ )を光源 としてイメージコンバータカメラ(HADLAND PHOTONICS 社製, IMACON 790, 最大こま撮り間 隔 $20000000 こ ま / s$, 最高流し速度 $1 \mathrm{~ns} / \mathrm{mm}$ )を使用 したストリーク写真撮影法によって行った。ストリー ク写真撮影は, $X$ 方向への水中衝擊波の伝ば過程を

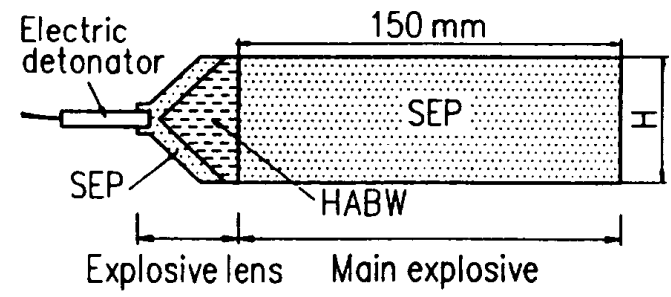

Fig. 2 A schematic of the formed explosives

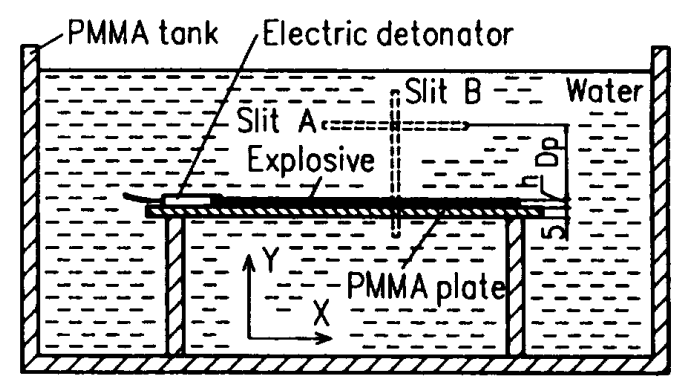

Fig. 3 An Experimental set up for the underwater explosion

調べるために図 3 中 A の位置にスリットをきった場 合と， $Y$ 方向への水中衝撃波の伝ば過程を調べるため にBの位置にスリットをきった場合について行った。 爆薬表面からスリットA まての距離 $D_{P}$ を種々変え て実験を行い, 発生した水中衝撃波の $X$ 方向速度を 調べた。これらの写真撮影では 6 号電気雷管 [旭化成 工業(株)製をを使用し、ディレイジェネレータ(HAD LAND PHOTONICS 社製, THREE CHANNEL DELAY GENERATOR, TYPE JH-3C DG)により SEP の起爆時間とキセノンフラッシュライトの発光 開始時間の制御を行った。また,ブロックダージを撮 影して距離の校正を行い，ディレイジェネレータの付 属機能により時間校正を行った。

$4 \cdot 2$ 数㯈計算方法 数值計算はALE 法を用い て行った。この方法の特徵は，異なった媒質が存在し ているような物理場も比較的容易に解析できるところ にある，さらに陰解法が容易に適用でき，解の安定性 の条件が陽解法に比へてて大き緩和され計算時間が短 縮できるという利点もある.計算は質量, 運動量, エネ ルギーの保存則に状態方程式を組合せて行った ${ }^{(15)}$. 水 およびPMMA 板については次式で表される MieGrüneisen の状態方程式を用いた。

$$
P=\frac{\rho_{0} C_{0}^{2} \eta}{(1-s \eta)^{2}}\left(1-\frac{\Gamma \eta}{2}\right)+\Gamma \rho_{0} e
$$

また爆ごう生成ガスの状態方程式は次式で表される JWL 状態方程式を用いた。 
Table 2 JWL parameters of SEP

\begin{tabular}{|c|c|c|c|c|c|}
\hline$A(\mathrm{GPa})$ & $B(\mathrm{GPa})$ & $R_{1}$ & $R_{2}$ & $\omega$ & $e_{0}(\mathrm{~J} / \mathrm{kg})$ \\
\hline 364.99 & 2.3097 & 4.30 & 1.00 & 0.28 & $2.16 \times 10^{6}$ \\
\hline
\end{tabular}

$$
\begin{aligned}
P & =A\left(1-\frac{\omega}{R_{1} V}\right) \exp \left(-R_{1} V\right) \\
& +B\left(1-\frac{\omega}{R_{2} V}\right) \exp \left(-R_{2} V\right)+\frac{\omega \rho_{e} e}{V}
\end{aligned}
$$

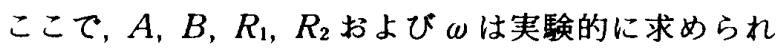
る定数(JWLパラメータ)であり，Vは爆楽の充てん 密度と爆ごう生成ガスの密度比 $\left(\rho_{e} / \rho\right)$ である.SEP の JWL パラメータを表 2 に示す[前出文献 (8) を参照].

爆薬の爆ごう過程の数值シミュレーションは, 次の ような仮定で行った（（a)爆薬は均質である。（b)爆 楽は完全に定常的爆ごうを行う。（c）爆ごう波が到達 した爆薬部は直ちに爆ごう生成ガスに変換される。 (d)爆ごう波のすぐ後方は Chapman-Jouget 点にお ける圧力, 密度, エネルギーを有する. ( e ) 爆ごう生成 ガスは JWL 状態方程式に従って膨張する。

計算場は一辺を $0.5 \mathrm{~mm}$ の格子に分割し，格子数は $X$ 方向に $480, Y$ 方向に 200 とした。なお計算は GATEWAY 2000(P 5-133)で行った。代表的な計算で は 1 回あたりの計算時間はおよそ $6 \mathrm{~h}$ であった。

\section{5. 結果および考察}

$5 \cdot 1$ 水中街夏波の伝ぱ過程爆薬表面からの距 離 $D_{P}$ を変化させ, 爆薬のなが手方向にスリット(図 3 中スリット A)をきって撮影したストリーク写真をも とに得られた波動線図を図 4 に示す。図 4 中黒抜きの プロットが, $H=120 \mathrm{~mm}, h=3 \mathrm{~mm}$ の場合について 得られた結果を, 白抜きのプロットが $H=50 \mathrm{~mm}, h$ $=5 \mathrm{~mm}$ の結果をそれぞれ示す。また実線の傾きはあ らかじめ実験的に求められた SEP の $D$ を示す。いず れの距離においても得られた実験結果はその実線と重 なることが図 4 からわかる，このことより本論文で提 案した理論の仮定 (2)に妥当性があることがわかる. 爆薬の板厚方向にスリット(図 3 中スリット $\mathrm{B}$ )をきっ て得られたストリーク写真の代表例を図 5 に示す。図 5 中の SW は水中衝撃波のストリークである.この写 真を光学顥微鏡を用いて観察し, 距離と時間のデー夕 を得た。それらを nonlinear curve fitting 法(16)により 次式のように関数近似した。

$$
\begin{aligned}
Y & =A_{1}\left\{1-\exp \left(-B_{1} t\right)\right\}+A_{2}\left\{1-\exp \left(-B_{2} t\right)\right\} \\
& +A_{3}\left\{1-\exp \left(-B_{3} t\right)\right\}+C_{0} t \cdots \cdots \cdots \cdots \cdots(13)
\end{aligned}
$$

なお $A_{1}, A_{2}, A_{3}$ および $B_{1}, B_{2}, B_{3}$ は定数である. 式

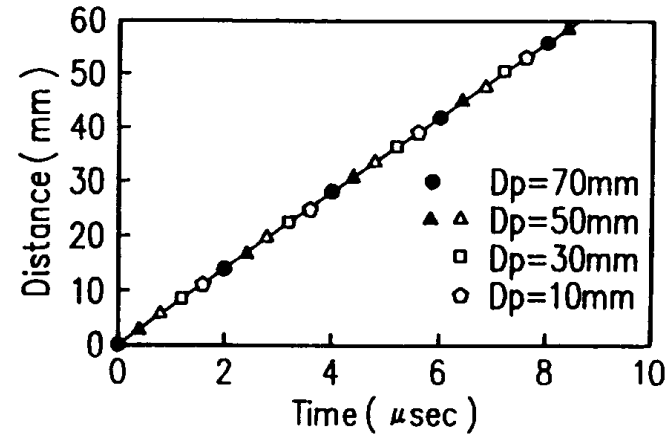

Fig. 4 Distance-time wave diagrams obtained by the streak photographs taken in $X$ direction

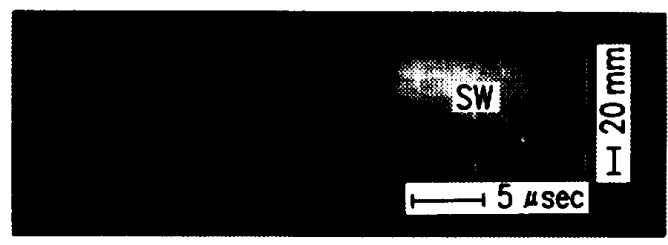

Fig. 5 An example of the streak photographs

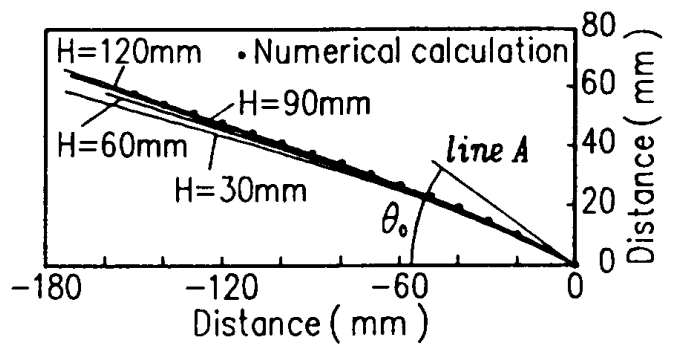

Fig. 6 A comparison of the profiles of the underwater shock wave

(13)を $t$ に関して微分し $t$ を大きくすると $d Y / d t$ は 急激に $C_{0}$ に漸近する。これは水中衝撃波の速度が時 間の経過により音速にまで減衰すると仮定して近似式 を决定したことによる，この近似式と仮定 (2)を組合 せると水中衝撃波の形状を得ることができる[前出文 献(15)を参照].これらの結果を図 6 に示す. 図6の横 軸は爆ごう波先端を零としてそれから下流方向にとつ た距離を示す.縦軸は爆楽表面からの $Y$ 方向距離を示 す.図 6 中 (๑)は $h=3 \mathrm{~mm}$ の場合に数值計算によっ て得られた結果を示し, 実線が $h=3 \mathrm{~mm} て ゙ H=30$, $60,90,120 \mathrm{~mm}$ の場合の結果をそれぞれ示す. $H=30$ $\mathrm{mm}$ の場合, 爆薬の表面から $Y$ 方向に $20 \mathrm{~mm}$ 程度ま では数值計算結果ならびにその他の結果と一致してい るが, 距離が大きくなるにつれてそれらから離れてい く傾向があることが図 6 からわかる.また幅 $H$ が大き くなるにつれてその離れていく筒所が上方に向かって いることも定性的にわかる。このことは爆薬側端面か ら発生した膨張波の影響が爆楽中央部付近上方の水中 


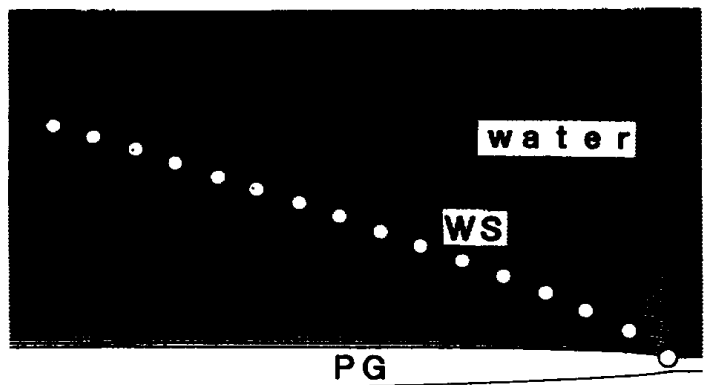

PMMA

Fig. 7 Distribution of Mach lines in the stationary coordinate system and the profiles of the underwater shock wave

衝撃波にまで及んでくることを示す. $H=90 \mathrm{~mm}$ 以上 では爆楽の表面から $Y$ 方向に $60 \mathrm{~mm}$ 程度までは側 端の影笽はほとんどみられないことがわかる。また図 6 中の line A は爆ごう生成ガスと水との間にインピ 一ダンスマッチング法を適用して求めた接線角の理論 的初期值 $\theta_{0}$ の傾きをもつ值線を示す. $\theta_{0}$ は 35.4 であ った。この直線が図 6 に示された水中衝撃波の形状と $(0,0)$ 点近傍で接していることから，接線の初期角の 理論值と実験值および計算値はきわめてょく一致する ことがわかる.このことは爆楽の水中爆ごうによって 発生した水中衝擊波の形状を理論的に得るために初期 角として $\theta_{0}$ が採用できることを示している。

図 7 は数値計算によって得られた定置座標系で示し たマッ八線分布を示す、マッ八線の密な部分が水中衝 撃波の形状(WS) を表す。図 7 中 $\mathrm{PG}$ は爆ごう生成ガ スを示す.また（○)は $h=3 \mathrm{~mm}, H=120 \mathrm{~mm}$ の場合 に撮影されたストリーク写真から得られた水中衝撃波 の形状である，両者がきわめてょく一致することが図 7 からわかる.このことは，理論解析で用いた仮定 (3) が有効であることを示している，水中衝撃波速度が式 (1) から得られると運動量保存則よりその前後の压力 比が求まる。その結果を図 8 に示す。図 8 中横軸は $h$ で無次元化された爆薬表面からの $Y$ 方向距離を，䋛 軸は水中衝撃波前後の圧力比を示す（○）は実験結果 を，実線は数値計算結果を示す。両者はきわめてよく 一致することがわかる.

\section{$5 \cdot 2$ 水中街慗波の形状と強さ $h=3 \mathrm{~mm}$ の場合} に数值計算から得られた等圧線図を図 9 に示す。図 9 中の(○)は数值計算によって得られた爆ごう生成ガス と水との境界 (WB) 上の点，(○）はその点およびその 点での压力, 密度等をもとに理論式 (1)〜（10）を用い て求めた水中衝撃波の位置を示す。図 9 で等圧線が密 なところが水中衝撃波の形状(WS)に対応している。

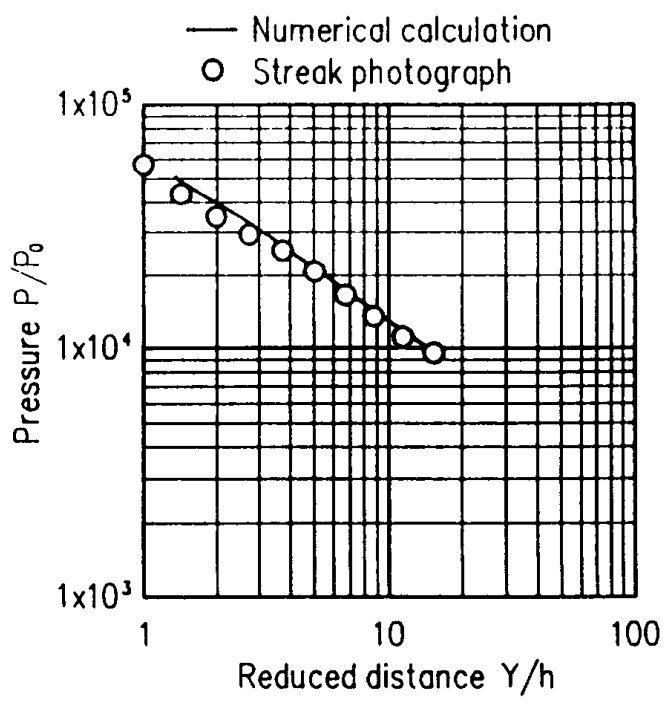

Fig. 8 Pressure distribution of the underwater shock wave

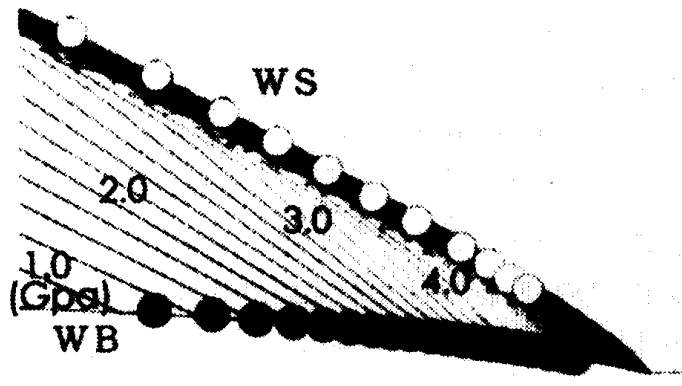

Fig. 9 Pressure contour maps obtained by numerical calculation and the boundary between product gas and water

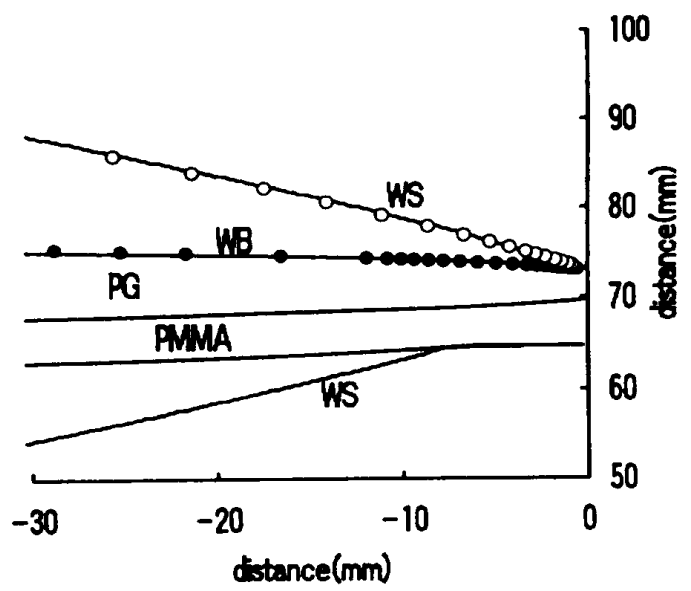

Fig. 10 The profiles of the underwater shock wave and the boundary between product gas and water

WS と本論文で提案した理論により得られる水中衝撃 波の形状はきわめてよく一致することがわかる．実験 および数値計算によって得られた水中衝撃波の形状を 図 10 に示す。図 10 には数値計算によって得られた爆 


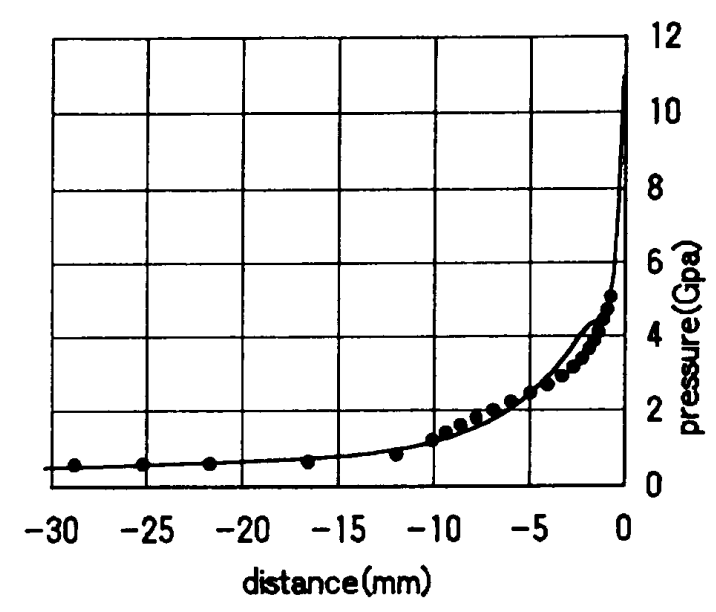

Fig. 11 Pressure distribution of product gas

ごう生成ガスと水ならびに PMMA との境界をあわせ て示す. 実線 WS は数值計算によって得られた水中衝 擊波形状を示し，（○）が水中重擊波の実験結果を示 す.図 10 中(・)は実験的に得られた水中衝撃波の形状 ならびに強さをもとに, 理論式(1)〜(10)を用いて得 られた爆ごう生成ガスと水との境界を表す。また実線 WB は数值計算によって得られた爆ごう生成ガス (PG) と水との境界を示す. 横軸の原点 0 は爆ごう波の 先頭を示す。理論的に得られた(・)で示される境界は PMMA 板の影響を考慮していないがWB とよく一 致することがわかる。

理論から得られた爆ごう生成ガス内の圧力分布を図 11 に示す. 図 11 中実線は数值計算結果を示し，(•) は特性曲線から得られた結果を示す。数值計算結果は PMMA 板の効果を考慮に入れているが，理論にはそ の影響が見積もられていない，そのため両者の圧力值 には少し違いがみられる.この違いは, PMMA と水の 音響インピーダンスの差に起因するものと考えられ る.

このように爆ごう生成ガスと水との境界の物理值を 用い特性理論式によって水中衝撃波の形状を十分有効 に予測しうることがわかった。 また水中衝撃波の形状 から爆ごう生成ガスの膨張過程も比較的よく説明でき ることが明らかになった，水中衝撃波の強さは爆ごう 生成ガスの膨張の影響をきわめて大きく受けることが わかった，以上のことより水中衝撃波の形状変化がわ かれば, 爆ごう生成ガスの水中での膨張過程を理論的 に解明することが可能であることがわかった。

\section{6. まと め}

高性能爆薬の水中爆ごうにより発生した水中衝擊波
の基本特性を光学的写真観察ならびに数値計算によっ て調べた。爆ごう波を固定した座標系について特性式 を応用し水中衝擊波ならびに爆ごう生成ガスの膨張に 関する理論的な解析方法を提案した。この理論では次 のような仮定をたてた。（1）爆薬中を伝ぱする爆ごう 波は一定速度 $D$ で层ぱし，定常理想爆ごうを行う。 （2）水中衝擊波全体は $X$ 方向に一定速度 $D$ で移動す る.（3）流れ場全体に $X$ 方向に逆向きに速度 $D$ を加 えることによって爆ごう波ならびに水中衝撃波を静止 することができる.

このような仮定のもと，数值計算で得られた爆ごう 生成ガスと水との境界における，压力，密度等の物理 值を用いて理論的に求めた水中衝撃波の形状が実験結 果ならびに数值計算結果ときわめてよく一致すること を明らかにした．また光学撮影実験で得られた水中衝 撃波の形状から求められた爆ごう生成ガスと水との境 界は数值計算で得られた境界ときわめてよく一致する ことがわかった。爆ごう生成ガス内部の圧力值には PMMA 板と水との音響インピーダンスの違いの影響 が多少みられた。なお実験は熊本大学工学部付置衝擊 エネルギー実験所で行われた。実験に際し実験所の石 谷氏に負うところが大きい。ここに謝意を表す。

\section{文献}

(1) Itoh, S., Fujita, M., Nagano, S. and Kamohara, K., Shock Waves@Marseille, (1995), 289-294.

（2）藤田昌大・ほか 4 名, 塑性加工学会請論集, 36-412 (1995), 541-544.

（3）伊東繁・ほか 5 名, 機論, 61-588, B(1995), 217-222.

(4) Cole. R. H., Undenwater Explosions. (1948), Princeton University Press.

(5) Sternberg, H. M. and Walker, W. A., Phys. Fluids, 14 9(1971), 1869-1878.

(6) Lee, E. L., Hornig, H. C. and Kury, J. W., UCRL50422 (1968).

(7) Amsden, A. A., Ruppel, H. M. and Hirt, C. W., LA8095, UC-32(1980).

（8）伊東繁・ほか 4 名，火薬学会誌，55-5(1994)，202-208.

（9）伊東繁・ほか 7 名, 火薬学会誌, 56-5(1995), 181-187.

(10) Itoh, S., ほか 4 名, Proc 1995 Joint ASME/JSME PVP Conf., 299(1995), 39-45.

(11) Prehl, P., Hornemann, U, and Heilig, W., Shock Tube Shock Wave Res., (1977), 303-312.

(12）田中克巳, 工業火薬, 37-6(1976), 277-290.

(13) Marsh, S. P., LASL Shock Hugoniot Data, (1980), 446575, University of California Press.

（14）高灀勝彦 - 村田健司 - 加藤幸夫，工業火薬，54-4 (1993), 190-197.

（15）伊東繁・吉良章夫・艮野司郎・藤田昌大，火薬学会誌， 56-5(1995), 188194.

(16) Berventon, P. R., Date Reduction and Error Analysis for the Physical Sciences, (1969), 204-246, McGraw Hill, New York. 